\title{
Validation of swath processed Cryosat-2 SARin data with different validation datasets at four different locations
}

\author{
Havelund, Natalia; Sørensen, Louise; Simonsen, Sebastian
}

Publication date:

2021

Document Version

Publisher's PDF, also known as Version of record

Link back to DTU Orbit

Citation (APA):

Havelund, N., Sørensen, L., \& Simonsen, S. (2021). Validation of swath processed Cryosat-2 SARin data with different validation datasets at four different locations. Abstract from EGU General Assembly 2021.

\section{General rights}

Copyright and moral rights for the publications made accessible in the public portal are retained by the authors and/or other copyright owners and it is a condition of accessing publications that users recognise and abide by the legal requirements associated with these rights.

- Users may download and print one copy of any publication from the public portal for the purpose of private study or research.

- You may not further distribute the material or use it for any profit-making activity or commercial gain

- You may freely distribute the URL identifying the publication in the public portal

If you believe that this document breaches copyright please contact us providing details, and we will remove access to the work immediately and investigate your claim 
EGU21-11985

https://doi.org/10.5194/egusphere-egu21-11985

EGU General Assembly 2021

(c) Author(s) 2021. This work is distributed under

the Creative Commons Attribution 4.0 License.

\section{Validation of swath processed Cryosat-2 SARin data with different validation datasets at four different locations.}

Natalia Havelund, Louise Sørensen, and Sebastian Simonsen

DTU Space, DTU, Kgs. Lyngby, Denmark (naand@space.dtu.dk)

Monitoring the Ice Sheets and ice caps in the polar region is important in a changing climate, and especially the coastal regions, which is the area that is most sensitive to changes in the climate and contributes to the global sea level rise (Gardner et al., 2013).

In this study, swath processed CryoSat-2 ice surface elevations are validated at four different locations with four different types of validation datasets; The Petermann Glacier and Nioghalvfjerdsfjorden Glacier in Northern Greenland, the Helheim glacier in the Eastern Greenland, and the ice cap of Austfonna located in Svalbard. The validation data consist of X-band radar data, Operation ICEBridge, ICESat-2 laser data, and Airborne Laser Scanner data respectively.

Swath processing improves the radar data coverage compared to conventional retracking, though, the extra amount of data leads to lower signal-to-noise ratio (Foresta et al., 2018), making validation of the swath processed data immensely important. Using different validation datasets allow us to investigate how the validation is impacted by the different platforms' ability to measure the surface topography.

\section{Bibliography:}

Foresta L, Gourmelen N, Weissgerber F, Nienow P, Shepherd A and Drinkwater M (2018) Heterogeneous and rapid ice loss over the Patagonian Ice Fields 2 revealed by CryoSat-2 swath radar altimetry. Remote Sensing of Environment, (minorrev(March), 0-1, ISSN 00344257 (doi: 10.1016/j.rse.2018.03.041)

Gardner AS, Moholdt G, Cogley JG, Wouters B, Arendt AA, Wahr J, Berthier E, Hock R, Pfeffer WT, Kaser G, Ligtenberg SRM, Bolch T, Sharp MJ, Hagen JO, van den Broeke MR and Paul F (2013) A Reconciled Estimate of Glacier Contributions to Sea Level Rise: 2003 to 2009. Science, 340(6134), 852-857, ISSN 0036-8075 (doi: 10.1126/science.1234532) 
